Andersen, L. S. \& Friend, C. 1973: Structure of the Ravns Storø amphibolite in the Fiskenæsset region. Rapp. Grønlands geol. Unders. 51, 37-40.

Berthelsen, A. \& Bridgwater, D. 1960: On the field occurrence and petrography of some basic dykes of supposed pre-Cambrian age from the southern Sukkertoppen district, West Greenland. Bull. Grønlands geol. Unders. 24 (also Meddr Grønland 123, 3), 43 pp.

McGregor, V. R. 1973: The early Precambrian gneisses of the Godthåb district, West Greenland. Phil Trans R. Soc. Lond. A, 273, 343-358.

McGregor, V. R. \& Bridgwater, D. 1973: Field mapping of the Precambrian basement in the Godthåbsfjord district, southern West Greenland. Rapp. Grønlands geol. Unders. 55, 29-32.

Myers, J. S. 1973: Igneous structures and textures in the Majorqap qâva outcrop of the Fiskenæsset anorthosite complex. Rapp. Grønlands geol. Unders. 51, 47-53.

Pankhurst, R. J., Moorbath, S., Rex, D. C. \& Turner, G. 1973: Mineral age patterns in ca. $3700 \mathrm{my}$ old rocks from West Greenland. Earth planet. Sci. Lett. 20, 157-170.

Windley, B. F. 1969: Evolution of the early Precambrian basement complex of southern West Greenland. Spec. Pap. Geol. Ass. Canada 5, 155-161.

Windley, B. F., Herd, R. K. \& Bowden, A. A. 1973: The Fiskenæsset complex, West Greenland. Part 1: A preliminary study of the stratigraphy, petrology, and whole rock chemistry from Qeqertarssuatsiaq. Bull. Grønlands geol. Unders 106 (also Meddr Grønland 196, 2) $80 \mathrm{pp}$.

V.R.M.

Atangmik,

3912 Sukkertoppen,

Greenland.

\title{
INVESTIGATIONS ON THE GRANULITES OF SOUTHERN NORDLAND, GODTHÅBSFJORD, CENTRAL WEST GREENLAND
}

\section{Robert Macdonald}

The rocks of the Nordland (Akia) peninsula lying west of Godthåbsfjord (the Nordland Complex of Noe-Nygaard \& Ramberg, 1961) are regarded as part of the Greenland Archaean Craton (Bridgwater et al., 1973). Reconnaissance surveys prior to 1973 by B. F. Windley of GGU amplified Noe-Nygaard and Ramberg's statement that the complex is made up principally of intensely metamorphosed and migmatised rocks generally at the granulite facies grade which show diapthoresis in places. A minor part of the complex has also been regarded as supracrustal and anorthosites are present.

Systematic mapping was begun in 1973 by the present author in the extreme southern part of Nordland with a view particularly to working out metamorphic grade, structural relationships and a basis for correlation with the increasingly well-known Nûk, Amitsoq and other units on the eastern side of Godthåbsfjord (see McGregor, 1973; Bridgwater \& McGregor, this report). 


\section{Rock units of the Nordland Complex}

Of the $240 \mathrm{~km}^{2}$ of the country mapped during the season, the greater part is underlain by rocks of dioritic through to quartz dioritic and granodioritic composition, most of which appear to be at granulite facies grade. These are named collectively the Akia granulites - the term granulite being used in a metamorphic facies sense, to mean a rock which shows evidence of being, or having been, at granulite facies grade. They outcrop throughout the main islands of Kangeq and Eqalunguit as well as north to the Nordland mainland across to Kûa inlet and Nipisat Sund. In a few places the Akia granulites contain small welldigested inclusions of basic and ultrabasic material, but characteristically they are homogeneous and fine-grained rocks with a weak pervasive foliation. Locally this weak foliation gives place to stronger foliation or even to banding structures which are seen to be mimetic upon an earlier, presumed amphibolite facies fabric. Randomly orientated pyroxenes in these granulites have replaced, as even grained aggregates, an earlier fabric with preferred orientation which appears to have been expressed in amphiboles.

To the west along the fringe of small islands, and in narrower belts elsewhere, the Akia granulites give way to a complex dominated by strongly banded granulites. Some of these have inclusions and slices of dioritic to granodioritic material of Akia granulite type. Others of the banded granulites have paler and more diffuse layers suggesting an earlier digestion of leucocratic material.

To the north-west, particularly around Uiania and the far west islands of Satsigsunguit the banded complex commonly contains enclaves and pods of gabbro-anorthosite. These enclaves range up to $25 \mathrm{~m}$ or so in length and occur in all stages of deformation, from primary material with coarse plagioclase crystals $15 \mathrm{~cm}$ or more long, through a softened and stretched form to distinctive looking banded granulites.

Basic and ultrabasic rocks occur generally throughout southern Nordland in impersistent layers, usually fragmented and boudinaged into trains of small inclusions or xenoliths. Some of the ultrabasic rocks or 'skarns' have distinctive apple-green diopsidic cores and darker (hornblendic?) rims. Larger masses up to $100 \mathrm{~m}$ or more long and about half as wide occur along the Godthåbsfjord coast north of Nipisat Sund and further inland, and in a belt which extends to about one kilometre wide along the north-west coast, by the islands of Tûdglínguit pâqússuat. This basic belt through Tûdglínguit pâqússuat comprises basic granulites with a distinctive striped appearance and sporadic skarn trains. In the same general area, and to the south-east along Ulitarfik inlet, there are a few narrow zones of rusty-weathering rocks, some with discernable garnet, suggestive of a sedimentary or supracrustal origin.

The complex of rocks described above is invaded by leucocratic granite which is now generally elevated, like the rocks it invades, to the granulite facies. The term Kûa granulite is proposed for this material. The rock is typically rather 
coarse, with a weak foliation, and is leucocratic. The principal constituents are quartz and feldspar with some pyroxene and hornblende, and the feldspar is rather pale, giving the rocks a pinkish or lilac tinge. The main granite mass lies west-central in the area, mostly north of Kûa inlet, but around it is spread a net of veins and migmatite which pervades in one manner or another into every part of the area mapped. Agmatites are common in many areas and some are extremely coarse with individual enclaves up to $20 \mathrm{~m}$ long. Some of the migmatites are also much digested and assimilated.

\section{Fold structures}

The main foliation and banding surfaces are generally folded rather openly with a steep easterly vergence on axes trending NNE-SSW. These folds plunge generally to the south at low angles, but plunges of as much as $60^{\circ}$ are encountered locally. Due to a paucity of marker horizons, individual folds have not been traced on the ground, but an analysis of photogeological linear features and structural data suggests that fold wave lengths up to about 2-3 km are present. Parasitic, minor isoclinal and intrafolial folds occur in some places and mainly support the concept of a general easterly vergence. Mineral lineation, expressed in mineral alignments or rods, is not uncommoniy encountered. This lineation is generally coaxial with the intrafolial folds and regional folds. To the west, in the domain of the banded granulites and the Tûdglínguit pâqússuat basic belt, planar and linear structures are congruent, but the foliation and banding surfaces are sub-vertical, suggesting tight closure of the NNE-SSW regional folds.

\section{Precedence of the Kâa migmatisation}

The Kûa granulite in places net-veins the Akia granulites in a non-directional or atectonic setting. Late dykes of Kûa-type granulite are also recorded. Elsewhere, however, banded granulites with a Kûa-type neosome are entirely involved in the regional folding, for there are passages from migmatites, agmatites, etc. into intensively drawn out and sheared granulites. The latter to some extent, because of recrystallisation under granulite facies conditions, simulate a normal banded migmatite, but are distinguished by their regularity, the presence of shear-offs and the lack of net-veins apart from some late (post-tectonic) segregations and 'sweats' of coarser material. These drawn-out and sheared rocks outcrop in definable zones characterised by shallow, and generally, westerly, dips. It is concluded for the present that the Kûa granulite, in the form of granite, migmatised the Akia complex which by then had already acquired its foliation and banding structures and other features of the amphibolite facies metamorphism, and that continued tectonism subsequently reworked part of the migmatite complex. The general congruency of fold structures in many of the Kûa and pre-Kûa rocks suggests, moreover, that the body of the Kûa material may have already been in 
place from an early stage and was remobilised during the migmatite phase in latetectonic times.

\section{Late intrusives}

The combined Akia and Kûa complex is cut by veins, pegmatites, aplites and dolerite dyke intrusions, which group quite distinctively and have a clear precedence of intrusion. These in sequence are:

Type 1. 'Grey dykes' $2-10 \mathrm{~cm}$ wide, and exceptionally as much as $1 \mathrm{~m}$, are ubiquitous. These are fine-grained, extremely homogeneous, apparently dioritic in composition and normally discrete and straight.

Type 2. Hornblende pegmatites. These are discrete, straight, of uniform width and mainly dip north at steep angles. The majority are 7 to $15 \mathrm{~cm}$ wide but some larger composite types reach over a metre.

Type 3. Muscovite-biotite pegmatites. Normally distinctively thick $(1-3 \mathrm{~m}$, but exceptionally $15 \mathrm{~m}$ or more), persistent and shallow dipping to the east. In places they contain tourmaline, garnet and beryl.

Type 4. Biotite pegmatites. These are discrete, straight, dilatational and typically between 5 and $15 \mathrm{~cm}$ wide. They mostly strike NNE and dip steeply to the east.

Type 5. Quartz-feldspar pegmatites. These are less uniform in width and direction than type 4 and they have no common regional strike. Associated with these pegmatites are late aplitic, quartzo-feldspathic and quartzose stringers of no particular orientation.

Type 6. Olivine dolerite dykes. Several vertically inclined dykes up to $50 \mathrm{~m}$ or so wide with a NNE regional trend can be traced for several kilometres.

Type 7. Dolerite dykes. These are much more abundant than type 6 dykes. They are similar in width, have approximately east-west strike and mainly dip steeply to the south. Some trace right across the area.

\section{Shear and reworking tectonism}

The granulite complex and the pegmatites are cut, particularly in the south, by many shears, mylonite and sub-mylonite zones and narrow zones of tectonically reconstituted rocks which due to colour accentuation caused by retrogressive reworking stand out as bleached tracts. These zones are steeply dipping and lie in two distinct sets striking respectively NNE-SSW and E-W.

\section{Synthesis and chronology}

Most rocks of the Nordland Complex appear to be at or very near to granulite facies grade. On one of the islands of the Arfiorfik group there is a $20 \mathrm{~cm}$ wide 
dyke of rather coarsely crystalline 'sweat' associated with the Kûa granulite. This and a few similar dykes contain bluish quartz and resinous feldspars typical of the granulite facies. The hornblende pegmatites also have a granulite appearance and it seems likely that the 'grey dykes' which they cut have similar grade where they cut granulite facies rocks. As these intrusives are all undeformed, it is inferred that granulite facies conditions prevailed until at least a very late or posttectonic phase. The granulite facies recrystallisation in the Akia granulites mimetic upon an earlier lower grade fabric is also evidence not only for prograde metamorphism, but suggests that granulite facies recrystallisation took place after the folding deformation. This implies that plastic and mobilisation structures in the complex were not acquired during the stage of granulite facies metamorphism, but during preceding stages which presumably culminated in amphibolite facies conditions.

Retrogressive metamorphism appears to be confined to late reworking and shear zones. The reworking is spatially congruous with some granulite facies shear foliations of the pre-Kûa cycle, for they both strike in the regional direction NNE-SSW. This suggests a continued history of shear movements before and after the culmination of granulite facies metamorphism.

The main sequence of events in southern Nordland may be outlined as follows:

1. Formation (or emplacement) of the Akia and the Kûa granulites, possibly as part of an interstratified igneous complex.

2. Main deformation of the complex to produce foliations and locally more intensely foliated or banded rocks and early reworked zones. These were folded on NNE-SSW axes. At about this time the banded complex was formed in the west, and included in this tectonism was the shearing in of the gabbroanorthosite enclaves.

3. Mobilisation of the Kûa granite and production of its migmatite screen. Continued folding culminated in shearing of some of the migmatite in zones with mainly a shallow westerly dip, while limited mobilisation and late injection of the Kûa material continued.

4. Cessation of folding and mobilisation, production of the final 'sweat' of the Kûa phase, followed by intrusions of 'grey dykes' and hornblende pegmatites. The complex attained granulite facies during this phase, culminating a little before the hornblende pegmatite intrusions.

5. Phases of pegmatites types 3,4 and 5, probably emanating from later granites (including the Qôrqut granite) east of Godthåbsfjord.

6. Reworking probably continued in linear zones throughout phases 3-5, but now culminated in a period of active localised shearing and diapthoresis.

7. Intrusion of dolerite dykes, types 6 and 7 , in two main phases. 
References

Bridgwater, D., Watson, J. \& Windley, B. F. 1973: The Archaean Craton of the North Atlantic region. Phil. Trans. R. Soc. Lond. A, 273, 493-512.

McGregor, V. R. 1973: The early Precambrian gneisses of the Godthåb district, West Greenland. Phil. Trans. R. Soc. Lond. A, 273, 343-358.

Noe-Nygaard, A. \& Ramberg, H. 1961: Geological reconnaissance map of the country between latitudes $69^{\circ} \mathrm{N}$ and $63^{\circ} 45 \mathrm{~N}$, West Greenland. Map Grønlands geol. Unders. 1 (also Meddr Grønland 123,5) 2 sheets, 9 pp.

Department of Geology, Makerere University, P.O. Box 7062, Kampala, Uganda.

\section{FIELD WORK ON THE VERY EARLY PRECAMBRIAN ROCKS OF THE ISUA AREA, SOUTHERN WEST GREENLAND}

\section{David Bridgwater and V. R. McGregor}

During the regional mapping programme in the Godthåbsfjord region (see Bridgwater \& McGregor, this report p. 39) D. B. and V. R. M. spent 14 days in the Isua area near the margin of the Inland Ice, approximately $150 \mathrm{~km}$ north-east of Godthåb, in order to examine the Isua supracrustal suite and to determine its relation to the surrounding gneisses and to the geology of Godthåbsfjord.

The area had previously been mapped and reported on by Kryolitselskabet $\emptyset$ resund A/S. The general distribution of rock types and structure described by Kryolitselskabet Øresund geologists was confirmed during the summer, although there are considerable differences in final interpretation. Age determinations made on Isua gneisses by the Oxford isotope geology laboratory have given a $\mathrm{Rb} / \mathrm{Sr}$ whole rock date of $3700 \pm 140 \mathrm{~m} . y$. , which is identical, within analytical error, with $\mathrm{Rb} / \mathrm{Sr}$ whole rock isochron dates from the type Amitsoq gneisses near Godthåb (Moorbath et al., 1972). Ironstones from the supracrustals have given a $\mathrm{Pb} / \mathrm{Pb}$ whole rock isochron age of $3760 \pm 70 \mathrm{y} . \mathrm{m}$., which is thought to be the result of a metamorphic event that was accompanied by severe uranium depletion (Moorbath et al., 1973). At the time of writing the Isua rocks are thus the oldest known supracrustal succession on Earth and as such are of considerable interest because of the insight they may give about early conditions in the Earth's crust and atmosphere.

4 Rapport 65 